\title{
Etiology of a Tuber Rot and Foliar Blight of Potato Caused by Phytophthora nicotianae
}

\author{
Raymond J. Taylor, Julie S. Pasche, and Neil C. Gudmestad, Department of Plant Pathology, North Dakota State University, Fargo 58105
}

\begin{abstract}
Taylor, R. J., Pasche, J. S., and Gudmestad, N. C. 2015. Etiology of a tuber rot and foliar blight of potato caused by Phytophthora nicotianae. Plant Dis. 99:474-481.

Although Phytophthora nicotianae is not normally considered to be an important pathogen of potato (Solanum tuberosum), intermittent outbreaks of a foliar blight and tuber rot have been reported in the United States over the past 75 years. Due to the sporadic nature of these reports, little is known about the etiology of the disease in potato. However, foliar disease and tuber rots caused by this pathogen are usually centered near areas of standing water in the field and along pivot tracks. Moreover, soil particles adhering to the foliage of infected potato plants suggest that water splash is involved in P. nicotianae dissemination and infection. Soil infestation and water splash dissemination studies were conducted under greenhouse conditions to examine the role that zoospores of $P$. nicotianae may play in disease on potato. In the soil infestation study, inoculum of $P$. nicotianae was added to soil at four rates $\left(0.0,1.0 \times 10^{3}, 5.0 \times 10^{3}\right.$, and $4.0 \times 10^{4}$ zoospores $/ \mathrm{ml}$ ) and three timings (at planting and 7 and 14 days after planting). Direct infection of aboveground plant tissues was achieved via splash dissemination of inoculum onto potato foliage. All soil infestations significantly reduced emergence, with the exception

of the $1.0 \times 10^{3}$ zoospores $/ \mathrm{ml}$ treatment, and no plants emerged from soil infested with $4.0 \times 10^{4}$ zoospores $/ \mathrm{ml}$. Significant reductions in stem number were observed with infestations of $1.0 \times 10^{3}$ and $5.0 \times 10^{3}$ zoospores/ $\mathrm{ml}$ at planting and $5.0 \times 10^{3}$ zoospores $/ \mathrm{ml}$ at 7 days after planting. Progeny tuber infections were confirmed with infestations at $1.0 \times 10^{3}$ zoospores $/ \mathrm{ml}$ at planting and 7 days after planting. Lesions developed on leaflets, petioles, leaf axils, and stems in all water splash dissemination treatments within 3 days of inoculation, significant differences in the lesion number were observed, and disease severity generally was proportional to inoculum concentration. Relative area under the disease progress curve of the $5.0 \times 10^{3}$ and $4.0 \times 10^{4}$ zoospores $/ \mathrm{ml}$ splash dissemination treatments was significantly greater than the 0.0 zoospore and $1.0 \times 10^{3}$ zoospores $/ \mathrm{ml}$ treatments. Progeny tuber infections were observed with all water splash dissemination treatments but infection rates did not differ significantly among treatments. These studies confirm the hypothesis that water splash dissemination of $P$. nicotianae inoculum is a likely means by which infections of this pathogen are initiated in potato.
\end{abstract}

The oomycete Phytophthora nicotianae Breda de Haan (= P. parasitica Dastur) is a pathogen with an extensive and diverse host range that encompasses numerous families of woody and flowering plants and is capable of infecting over 300 species (14). This pathogen commonly causes root and crown rots, the most notable of which are black shank of tobacco (70) as well as foot rot, gummosis, and root rot of citrus species (68). P. nicotianae can also attack fruit, causing buckeye rot of tomato (60) and brown rot of citrus (68). The pathogen is a frequent problem in greenhouses and nurseries, where it usually causes root and crown rots, cankers, stem dieback, and foliar blights of annual herbaceous and perennial woody plant species $(15,33,41,50,57)$. P . nicotianae also has been reported to cause foliar blight and tuber rot of potato $(9,14,25,48,51,64,65)$ but has not been considered to be of major importance on this host (16). The number of recently confirmed cases of foliar and tuber infections of potato caused by P. nicotianae in Florida (2006), Michigan (2007 and 2009), Missouri (2007 and 2008), Nebraska (2005, 2006, and 2010), and Texas (2006, 2007, 2008, 2009, and 2010) $(64,65)$ suggests that the pathogen has become more prevalent and, thus, may be an emerging threat to potato production, particularly in warmer growing regions of the southern United States.

Symptoms of the tuber rot phase of $P$. nicotianae infections are similar to those associated with $P$. erythroseptica, the causal agent of pink rot, an important soilborne disease of potato tubers in the United States (58) and most other potato-growing areas in the world $(16,40,62)$. However, in the case of $P$. nicotianae, the pink discoloration of infected tuber cortical tissue is not as intense as $P$. erythroseptica infections and the tissue turns tan to brown after extended contact with

Corresponding author: N. C. Gudmestad; E-mail: Neil.Gudmestad@ ndsu.edu Accepted for publication 9 October 2014.

http://dx.doi.org/10.1094/PDIS-05-14-0519-RE

(C) 2015 The American Phytopathological Society the air (64). Foliar symptoms on potato may vary somewhat but leaf lesions usually are roughly circular in shape and surrounded by a chlorotic or pale-green halo. In severe cases, leaflets or entire leaves may be infected. Such similar-appearing lesions also may form on petioles and stems. P. nicotianae foliar infections of potato $(51,64)$ and tomato (1) resemble late blight of these crops caused by $P$. infestans. Despite the remarkable similarity between the symptoms of $P$. nicotianae foliar blight and late blight, the two can be differentiated by the appearance of their lesions. $P$. nicotianae lesions lack the downy growth typical of $P$. infestans and sporulation is rarely observed (64). Furthermore, $P$. nicotianae foliar infections often are confined to irrigation wheel tracks and low-lying areas having saturated soil or standing water: places where water-saturated soil would tend to be splashed onto foliage (64). The tuber rot phase, often seen in furrow-irrigated fields with heavy, clay soils (25), is likely to develop in these areas as well.

Little is known about disease etiology in potato but factors that limit such infections are probably similar to those known for other diseases caused by $P$. nicotianae. As with most Phytophthora spp., high relative humidity or the presence of free water are essential for disease development $(3,12,21,32,37)$ and dissemination of sporangia and zoospores $(21,26,32,35,39,52,53)$. Surface water is an important element in dispersal (12) because many species of Phytophthora, including $P$. nicotianae, have been isolated from irrigation water and runoff $(5,22,31,36,45,49,61,66,73)$.

Zoospores are the primary agents of dissemination of Phytophthora spp. In an aquatic environment, zoospores actively disperse by swimming and can be passively disseminated in flowing water. As a result, Phytophthora-induced diseases are often difficult to control. Zoospores can be released quickly when favored by the environment. Zoospores of $P$. parasitica (syn. P. nicotianae) have been observed in water added to naturally infested field soil after just 10 min (67). The aforementioned study also found that zoospores of $P$. parasitica can remain motile for up to $20 \mathrm{~h}$ and that the pathogen is able to survive in irrigation water as zoospores, hyphal fragments, and appressorium-like structures for up to 60 days. 
Under favorable conditions, zoospores may be released from sporangia produced on infected plant debris, infected plant tissues including roots and belowground stems, and free mycelium. They also can originate from zoospore cysts, oospores, and chlamydospores in the soil. Zoospores released from soilborne propagules generally function as secondary inoculum but may serve as primary inoculum under saturated conditions if they are moved by water to infect plants in noninfested soil $(28,72)$. Zoosporangial production and zoospore release have been correlated with pathogen virulence (10) and zoospores are generally considered to be the primary propagule responsible for intrafield spread of this pathogen $(30,54)$. The major species of Phytophthora can be categorized based upon method of dispersal, which includes root to root movement within the soil; distribution in surface water; splash dispersal from the soil to leaves, stems, and fruit; aerial dissemination from sporulating lesions on aboveground plant tissue; and movement of infested soil, propagules, or plants by human or invertebrate activity (55). Dispersal of $P$. parasitica has been documented with each of these except via human activity, but this is one possible mechanism responsible for new disease outbreaks in previously noninfested areas. Splash dispersal of spores from the soil to host plant leaves and stems or from infected to healthy plants has been documented for a diverse group of fungal genera $(17,24,44,56)$. The importance of rain for spore dispersal also has been noted in various Phytophthora spp. $(21,26,27,32,35,43,69)$, including $P$. parasitica, the causal agent of rhododendron dieback (37). In the case of foliar blight of potato, the association of disease development with saturated soils and areas of standing water suggest that splash movement of $P$. nicotianae zoospores from the soil or standing surface water potentially may be a mechanism responsible for initiating foliar infections and, thus, play an integral role in development of disease epidemics.

Because of the importance of zoospores in the etiology of Phytophthora diseases, this study was undertaken to assess how soilborne and splash-disseminated zoospore inoculum affect the development of $P$. nicotianae infections of potato. Previous studies demonstrated that infections could be induced by inoculating detached potato leaves and tubers postharvest $(51,64,65)$. The aggressiveness of $23 P$. nicotianae isolates from several host species, including potato, and the susceptibilities of 27 potato cultivars have been evaluated (65). The current study, focusing on disease etiology, was conducted as an extension of this comprehensive earlier work and is the first to investigate the dynamics of the P. nicotianae-potato interaction involving an intact whole-plant system. This research involved examining the interaction between zoospores and the host preemergence in the soil and postemergence after an aqueous zoospore-soil suspension contacted the plant surface via splash inoculation.

\section{Materials and Methods}

Growth of test plants. Two independent experiments were conducted to determine the role of zoospores in the development of tuber rot and foliar blight phases of P. nicotianae in potato. Single, whole (uncut) certified seed tubers of 'Russet Norkotah', a potato cultivar susceptible to $P$. nicotianae $(64,65)$, were planted in plastic pots (20 cm in diameter; National Polymers, Inc., Lakeville, MN) to a depth of approximately $5 \mathrm{~cm}$. The pots contained 2.3 liters $(3.1 \mathrm{~kg})$ of a mix of sand and Scotts Premium Topsoil composed of organic materials and sphagnum peat moss (The Scotts Company, Marysville, $\mathrm{OH}$ ) in a ratio of five parts sand to three parts Premium Topsoil. Pots were watered to saturation at planting and daily throughout the course of the experiments. After emergence, each pot received a single 11.3-g application of Osmocote 3-4 month Equation (15-9-12) time-release fertilizer (The Scotts Company). Plants were grown under greenhouse conditions with a supplemental incandescent $16-\mathrm{h}$ photoperiod per day and at ambient temperatures of 23 to $32^{\circ} \mathrm{C}$.

Inoculum production. Soil infestations and water-splash foliar inoculations were conducted using $P$. nicotianae isolate 06TX1-3. This isolate was recovered from a natural infection of potato foliage and has been characterized and used in previous inoculation studies $(64,65)$. Inoculum was prepared by initiating cultures in dishes containing clarified V8 juice (CV8) agar medium (100 ml of V8 juice plus $1 \mathrm{~g}$ of $\mathrm{CaCO}_{3}$ centrifuged in a Sorval $\mathrm{RC} 5 \mathrm{C}$ at 7,000 rpm for 5 min to remove pulp and clarify, and $900 \mathrm{ml}$ of deionized $\mathrm{H}_{2} \mathrm{O}$ ). After 3 days of incubation in an environmentally controlled chamber at $20 \pm 1^{\circ} \mathrm{C}$ in the dark, 3-mm-diameter disks containing mycelium and agar were removed from colony margins. Disks were placed in culture dishes (three per dish) and dishes were flooded with $11 \mathrm{ml}$ of autoclaved $10 \%$ V8 juice broth $(100 \mathrm{ml}$ of V8 juice centrifuged in a Sorval RC5C at 7,000 rpm for $5 \mathrm{~min}$ to clarify, and $900 \mathrm{ml}$ of deionized $\mathrm{H}_{2} \mathrm{O}$ ). After incubation for 3 days at $20 \pm 1^{\circ} \mathrm{C}$ in the dark, the V8 juice broth was suctioned from the dishes with a sterile pipet, and the mycelial mats were rinsed twice with $10 \mathrm{ml}$ of sterile deionized $\mathrm{H}_{2} \mathrm{O}$ and resuspended in $10 \mathrm{ml}$ of autoclaved $10 \%$ soil extract $(100 \mathrm{~g}$ of soil from a potato field and $900 \mathrm{ml}$ of deionized $\mathrm{H}_{2} \mathrm{O}$ ) to induce sporangial formation. Cultures were incubated under constant illumination by eight Sylvania F20T12/CW lamps in an environmentally controlled chamber at $20 \pm 1{ }^{\circ} \mathrm{C}$ until zoospores were released.

Sporangial primordia were observed on the washed mycelial mats after $1.5 \mathrm{~h}$ in the soil extract. Sporangia initials had formed by $2.5 \mathrm{~h}$ and a few motile zoospores were detected. A large number of sporangia (4 to 6 per $\times 100$ microscope field) had formed within $8 \mathrm{~h}$ and numerous swimming zoospores were noted in the soil extract suspension. Spontaneous mass release of zoospore occurred within 12 to $15 \mathrm{~h}$. Zoospore concentration was determined using a hemacytometer and adjusted to desired test concentrations via dilution with sterile, deionized $\mathrm{H}_{2} \mathrm{O}$. Zoospore suspensions were held at ambient room temperature $\left(20\right.$ to $\left.25^{\circ} \mathrm{C}\right)$ prior to use, generally within 15 to $45 \mathrm{~min}$. Zoospore suspensions were examined microscopically for viability within 30 min following soil infestation and foliar splash inoculations and zoospores were found to be active and motile.

Soil infestation. In total, seven soil treatments were evaluated to assess the importance of soil inoculum level and timing of infection of disease development caused by $P$. nicotianae. Soil was infested at planting with zoospore suspensions at $0.0,1.0 \times 10^{3}$, and $5.0 \times 10^{3}$ zoospores $/ \mathrm{ml}(0,32$, and 160 zoospores $/ \mathrm{kg}$ of soil, respectively). Zoospores also were applied to soil 7 days after planting (DAP) at concentrations of $1.0 \times 10^{3}, 5.0 \times 10^{3}$, and $4.0 \times 10^{4}$ zoospores $/ \mathrm{ml}$ $\left(32,160\right.$, and 1,282 zoospores $/ \mathrm{kg}$, respectively), and at $4.0 \times 10^{4}$ zoospores $/ \mathrm{ml}$ (1,282 zoospores $/ \mathrm{kg}) 14$ DAP. Individual pots received $100 \mathrm{ml}$ of a specific zoospore suspension followed by $100 \mathrm{ml}$ of sterile deionized $\mathrm{H}_{2} \mathrm{O}$. Pots treated in the same manner with sterile deionized $\mathrm{H}_{2} \mathrm{O}$ substituted for the zoospore suspension at planting served as noninfested controls. Five replicate pots were prepared for each of the infestation-timing treatments and the experiment was performed twice. Pots were arranged in a randomized complete block design (RCBD) on greenhouse benches having open-mesh grid surfaces. Soil temperatures ranged from 23 to $28^{\circ} \mathrm{C} 24 \mathrm{~h}$ after planting and soil infestation.

Splash dissemination. In a separate experiment, the role of splash-dispersed $P$. nicotianae zoospores was evaluated using four inoculum concentrations. Movement of $P$. nicotianae from the soil by water splash was simulated by treating plants with an aqueous slurry of the sand-topsoil and zoospore inoculum. Inoculum was diluted to $1.0 \times 10^{3}, 5.0 \times 10^{3}$, and $4.0 \times 10^{4}$ zoospores $/ \mathrm{ml}$ and $400 \mathrm{ml}$ of this suspension were transferred to $500-\mathrm{ml}$ shaker bottle containing $100 \mathrm{~g}$ of the soil mix. The bottle was closed with a plastic lid (3 $\mathrm{cm}$ in diameter) perforated with five evenly spaced, 3-mmdiameter holes. The soil-inoculum suspension was applied to the entire plant to uniform wetness by shaking. The soil surface was not covered but plants were tilted at a roughly $45^{\circ}$ angle to avoid depositing the suspension onto the soil in the pots during the splashinoculation procedure. Plants were shaken gently to remove excess inoculum and held at an angle until they no longer dripped. Each plant received approximately 80 to $90 \mathrm{ml}$ of soil-inoculum slurry in this manner. Plants treated in the same manner with the sand-topsoil mix suspended in sterile deionized $\mathrm{H}_{2} \mathrm{O}$ served as noninoculated controls. Plants were incubated in enclosed chambers at $25 \pm 1{ }^{\circ} \mathrm{C}$ in the dark for $24 \mathrm{~h}$ and misted with deionized $\mathrm{H}_{2} \mathrm{O}$ for $10 \mathrm{~s}$ at 2-min intervals. After misting, plants were returned to open-mesh greenhouse benches and arranged in an RCBD, spaced so that the foliage of adjacent plants did not come into contact. Five replicate pots were prepared 
for each inoculum treatment and the noninoculated control. The experiment was conducted twice as independent trials. Plants were inoculated 50 and 40 days after emergence (DAE) in the first and second trial, respectively.

Disease evaluations. The percentage of plants that emerged in the soil-infestation experiment was recorded and the emerged plants were examined weekly for the presence of lesions on leaves and stems typical of $P$. nicotianae infections. In the splash-dissemination experiment, foliar disease severity and development were evaluated by counting the number of lesions that developed on stems, leaves (total of all leaflets), petioles, and leaf axils 4 and 7 days after inoculation (DAI). Lesion number per plant was not evaluated beyond day 7; however, foliar disease severity was assessed at approximately weekly intervals through 40 DAI by estimating the percentage of foliage per plant having chlorotic or necrotic lesions and senescent foliage typical of $P$. nicotianae infections. Disease severity was transformed to area under the disease progress curve (AUDPC) (59). AUDPC values were normalized by dividing by the total area and the resulting relative area under the disease progress curve (RAUDPC) was used to compare treatments (19).

At harvest in both the soil-infestation and splash-dissemination experiments, the number and size of stem lesions and percentage of progeny tubers infected were determined. Representative lesions were selected at random from stem and leaf tissue in the splashdissemination experiment $7 \mathrm{DAI}$ and isolations were made to verify $P$. nicotianae infection. Tissue samples of approximately $3 \mathrm{~mm}^{2}$ were placed in culture dishes containing sterile water agar. After incubation at $25 \pm 1{ }^{\circ} \mathrm{C}$ in the dark for 7 to 10 days, culture dishes were examined for the presence of $P$. nicotianae. Isolates were identified as $P$. nicotianae based upon appearance of mycelium, size and shape of typical papillate sporangia, and comparisons with published descriptions for Phytophthora spp. $(14,20)$.

Infection of stems by $P$. nicotianae also was assessed at harvest in the soil-infestation experiment and at 40 DAI in the splashdissemination experiment by sampling and plating tissue followed by microscopic examination of recovered isolates. Stems were disinfected by immersion in $10 \%$ bleach solution for 5 min and rinsed in sterile deionized $\mathrm{H}_{2} \mathrm{O}$. Three tissue disks approximately 1 to $2 \mathrm{~mm}$ thick were excised from stem sections 0 to $5 \mathrm{~cm}$ above and below the soil surface via cuttings made perpendicular to the long axis. Every stem from each treatment was sampled in this manner. Disks were placed in culture dishes containing water agar and examined for the presence of $P$. nicotianae after 10 days. Isolates were identified as $P$. nicotianae as described above. Stem number, plant fresh weight, and tuber number and fresh weight were determined when tubers were harvested at the conclusion of both the soil-infestation and splash-dissemination experiments. Progeny tubers also were assessed at harvest via visual inspection for symptoms of rot typical of $P$. nicotianae and confirmation of infection by isolation from symptomatic tissue followed by microscopic examination of recovered isolates.

Data analysis. Levene's test for homogeneity of variance was conducted on the data from all soil-infestation and splashdissemination trials (46). A one-way analysis of variance was performed among inoculum concentrations for all data parameters using PROC GLM (SAS version 9.2; SAS Institute Inc., Cary, NC). Differences in mean plant emergence, disease incidence on inoculated foliage, stem number, stem fresh weight, tuber number at harvest, tuber fresh weight at harvest, disease incidence on progeny tubers, percentage of $P$. nicotianae isolates recovered from above- and belowground stem tissue at harvest, as well as mean weekly progression of disease severity and RAUDPC were determined using Fisher's protected least significant difference test $(\alpha=0.05)$.

\section{Results}

Soil infestation With $\boldsymbol{P}$. nicotianae zoospores. Plant emergence. Variances for plant emergence were homogeneous for the two soilinfestation trials and data were combined for analysis. The first plants emerged between 17 and 21 DAP. Emergence in the noninfested controls was $100 \%$, indicating the health of the seed used in these experiments and the lack of soilborne tuber rot pathogens in the potting mixture. Significant differences $(P<0.0001)$ in emergence were observed among zoospore soil infestation levels and infestation timings (Table 1). No plants emerged in soil infested with $4.0 \times 10^{4}$ zoospores $/ \mathrm{ml}$ at either 7 or 14 DAP. Although infestation at $1.0 \times$ $10^{3}$ and $5.0 \times 10^{3}$ zoospores $/ \mathrm{ml}$ at planting and $5.0 \times 10^{3}$ zoospores/ml 7 DAP all resulted in significant reductions in emergence relative to the noninfested control, emergence did not differ significantly among these three treatments. A significant reduction in emergence also was observed with $5.0 \times 10^{3}$ zoospores $/ \mathrm{ml}$ applied 7 DAP. Emergence $(90 \%)$ in soil infested with $1.0 \times 10^{3}$ zoospores $/ \mathrm{ml}$ at 7 DAP did not differ significantly from the noninfested control. All pots with no plant emergence were emptied between 21 and 28 DAP and the integrity of the tuber seed was assessed. Nearly all seed tubers were found to be completely decomposed, with only small sections of the periderm remaining in most pots. Some pots contained seed tubers that remained at least partially intact, with some having symptoms typical of $P$. nicotianae rot. The pathogen was successfully isolated from a single seed tuber with these symptoms as well as from an infected belowground shoot approximately $3 \mathrm{~cm}$ in length.

Plant growth and disease assessment. Variances for stem number, stem fresh weight, progeny tuber number, progeny tuber fresh weight, and progeny tuber infection were homogeneous for the two soil-infestation trials and data were combined for analysis. For those plants that emerged, stem number was reduced significantly with the $1.0 \times 10^{3}$ and $5.0 \times 10^{3}$ zoospores $/ \mathrm{ml}$ infestations at planting and with $5.0 \times 10^{3}$ zoospores $/ \mathrm{ml}$ at 7 DAP $(P<0.0001)$. However, significant differences were not observed in stem fresh weight $(P=0.2929)$, progeny tuber number $(P=0.0605)$, progeny tuber fresh weight $(P=0.7028)$, or progeny tuber infection rates $(P=0.2344)$ (data not shown). Stem lesions typical of $P$. nicotianae infections only were observed with infestation by $1.0 \times 10^{3}$ zoospores $/ \mathrm{ml}$ at $7 \mathrm{DAP}$ in one trial. This was confirmed when isolations were made from all stems collected at harvest. Additionally, progeny tuber infections were observed with $1.0 \times 10^{3}$ zoospores/ml at planting $(25.0 \%)$ and 7 DAP $(15.7 \%)$ but were not detected with any other infestation treatment or the noninfested control (data not shown).

Postharvest isolations. Variances for aboveground and belowground infections from the two soil-infestation trials also were homogeneous; therefore, these data were combined for further analysis. $P$. nicotianae infections were confirmed in both symptomatic and asymptomatic above- and belowground portions of stems in both trials following harvest. Isolates were recovered from 5 of 12 inoculated treatments across both trials having emerged plants; however, the rates of infection were inconsistent and significant differences among treatments were not observed in aboveground $(P=0.2393)$ and belowground $(P=0.3270)$ tissue. Isolates were recovered from both above- and belowground tissue from plants grown in soil infested with $1.0 \times 10^{3}$ and $5.0 \times 10^{3}$ zoospores $/ \mathrm{ml} 7 \mathrm{DAP}$ and from belowground tissue infested with $1.0 \times 10^{3}$ zoospores $/ \mathrm{ml}$ at planting (data not shown). Recovery rates ranged from 16.7 to $33.3 \%$ over these treatments. The pathogen was not recovered from the control plants grown in noninfested soil.

Table 1. Emergence of Russet Norkotah potato from soil infested with zoospores of Phytophthora nicotianae over a range of rates and timings ${ }^{\mathrm{z}}$

\begin{tabular}{llc}
\hline Infestation rate (zoospores/ml) & Timing & Emergence (\%) \\
\hline 0.0 & $\ldots$ & $100.0 \mathrm{a}$ \\
$1.0 \times 10^{3}$ & At planting & $40.0 \mathrm{~b}$ \\
$5.0 \times 10^{3}$ & At planting & $40.0 \mathrm{~b}$ \\
$1.0 \times 10^{3}$ & 7 DAP & $90.0 \mathrm{a}$ \\
$5.0 \times 10^{3}$ & $7 \mathrm{DAP}$ & $30.0 \mathrm{~b}$ \\
$4.0 \times 10^{4}$ & $7 \mathrm{DAP}$ & $0.0 \mathrm{c}$ \\
$4.0 \times 10^{4}$ & $14 \mathrm{DAP}$ & $0.0 \mathrm{c}$ \\
$P$ value & $\ldots$ & $<0.0001$ \\
\hline
\end{tabular}

${ }^{\mathrm{z}}$ DAP $=$ days after planting. Each treatment consisted of five replicate pots and the experiment was conducted twice. Means followed by the same letter do not differ significantly according to Fisher's protected least significant difference $(\alpha=0.05)$. $P$ value signifies the probability of observing a greater value with the $F$ test. 
Splash dissemination of $\boldsymbol{P}$. nicotianae zoospores. Foliar infection and disease progression. Variances of tissue-specific infection data for total leaf, petiole, and stem lesions per plant plus percentage of leaves infected from the individual trials were homogeneous and these data were combined for analysis. Foliar infections were not detected in the zoospore-free controls; however, disease incidence was $100 \%$ across both trials because all zoospore splash-dissemination treatments produced foliar infections. The incidence and severity of these infections were generally proportional to the concentration of the zoospore inoculum (Table 2), clearly indicating an inoculum rate response. Lesions appeared on leaflets, petioles, leaf axils, and stems of inoculated plants within 3 DAI. Lesions grew in size from the original infection site and often coalesced but did not spread to new foliage. Lesions were counted 4 and 7 DAI but, by day 7, lesions were either too numerous to count in some treatments or had coalesced to form larger lesions. As a result, only the data obtained from the day 4 evaluations were used to assess infection severity (Table 2). Significant differences in the number of leaf lesions $(P<0.0001)$, petiole lesions $(P=0.0003)$, stem lesions $(P=0.0085)$, and percentage of leaves infected $(P<0.0001)$ were observed. Variances of leaf axil infection data from the individual trials were not homogeneous and these data were treated separately. Infection rates for leaf axils were very low and did not differ significantly $(P=0.5483)$ from the non-zoospore-inoculated control in trial 2 (Table 2). However, significant increases in disease severity $(P=0.0033)$ were observed with the $5.0 \times 10^{3}$ and $1.0 \times 10^{4} \mathrm{zoospore} / \mathrm{ml}$ treatments in trial 1. Inoculum concentrations as low as $1.0 \times 10^{3}$ zoospores $/ \mathrm{ml}$ caused leaf, petiole, and leaf axil infections but this treatment did not cause leaf axil infections in trial 2 . In contrast, all tissues were infected following treatment with the higher inoculum rates of $5.0 \times 10^{3}$ and $1.0 \times 10^{4}$ zoospores $/ \mathrm{ml}$ and incidences of leaf infections were highest ( 72.6 and $85.8 \%$ respectively) with these treatments. Inoculation with $1.0 \times 10^{4}$ zoospores $/ \mathrm{ml}$ caused significantly more leaf, petiole, leaf axil, and stem infections than with the $1.0 \times 10^{3}$ zoospore $/ \mathrm{ml}$ treatment.

P. nicotianae was recovered from all lesions randomly sampled within 14 DAI. Small, water-soaked lesions approximately 1 to $2 \mathrm{~mm}$ in diameter developed on some control leaflets splashed with soil suspension in water. These lesions became necrotic and did not expand further. P. nicotianae was not recovered from random isolations made from these lesions or similar lesions that appeared on the inoculated plants; therefore, these were not considered in the $P$. nicotianae lesion assessments.

Variances of observations made 4, 7, 28, and 40 DAI were homogeneous. Because these estimates represent the levels of blight severity at early, mid, and late intervals in the development of foliar disease, all foliar disease ratings from trials 1 and 2 were combined to construct disease progression curves (Fig. 1). Significant differences were observed among these treatments at $P<0.0001, P<0.0001$, $P=0.0147$, and $P=0.0038$, respectively. Disease severity observed with treatments at $5.0 \times 10^{3}$ and $1.0 \times 10^{4}$ zoospores $/ \mathrm{ml}$ did not differ significantly 4,28 , and 40 DAI whereas the non-zoospore-inoculated control did not differ significantly from the treatment at $1.0 \times 10^{3}$ zoospores $/ \mathrm{ml}$. The extent of leaf chlorosis or necrosis of the treatment at $1.0 \times 10^{3}$ zoospores $/ \mathrm{ml}$ was nearly identical to natural senescence observed with the non-zoospore-inoculated control through 28 DAI but subsequently diverged and began to increase relative to that treatment. On all four observation dates, the two highest inoculum levels resulted in significantly greater blight severity relative to the non-zoospore-inoculated control and the $1.0 \times 10^{3}$ zoospores $/ \mathrm{ml}$ treatment. Total levels of leaf chlorosis or necrosis recorded at the conclusion of the experiment $40 \mathrm{DAI}$ were $72.4 \%$ with inocula at $5.0 \times 10^{3}$ zoospores $/ \mathrm{ml}$ and $66.7 \%$ with $1.0 \times 10^{4}$ zoospores $/ \mathrm{ml}$. These relationships are consistent with the RAUDPC results (Table 3).

Variances of the RAUDPC values calculated for each trial were not homogeneous and these data are reported here separately for each trial. Significant differences in the RAUDPC values associated with the disease severity were observed in trial $1(P=0.0008)$ but not in trial $2(P=0.0686)$ (Table 3$)$. Disease severity progressed in plants inoculated with $1.0 \times 10^{3}$ zoospores/ml but did not differ significantly from the noninoculated controls in trial 1 . Disease severities in plants inoculated with $5.0 \times 10^{3}$ and $1.0 \times 10^{4}$ zoospores $/ \mathrm{ml}$ were not significantly different but did differ significantly from treatment at $1.0 \times 10^{3}$ zoospores $/ \mathrm{ml}$ and the non-zoospore-inoculated controls in trial 1. Although significant differences in RAUDPCs were not observed among treatments in trial 2 , disease severity trends tended to parallel those observed in trial 1 . Separation of treatments was consistent throughout the course of the experiment and generally mirrored the lesion number results recorded as early as 4 DAI in the development of foliar blight.

Disease assessment at harvest. Variances for infection parameters, including lesion length, stems girdled, and progeny tuber infection from the individual trials, were not homogeneous and results from trial 1 and trial 2 are presented separately (Table 4). P. nicotianae infections were not observed in the non-zoospore-inoculated treatments (Table 4). Stem lesions developed with all zoospore-inoculated treatments in both trials. However, as observed with the number of foliar lesions on day 4 (Table 2) and estimations of RAUDPC (Table 3), infection efficiency expressed as lesion length and stems girdled was numerically higher in trial 1 than in trial 2 . As with the soil infestations, significant differences were not observed among several plant growth parameters, including stem number $(P=0.5687)$, stem fresh weight $(P=0.6349)$, tuber number $(P=0.4142)$, and tuber fresh weight $(P=0.2266)$ evaluated at harvest. Significant differences were observed among infection variables, including number of stem lesions $(P<0.0001)$, stem lesion length (trial 1) $(P=0.0089)$, and percentage of stems girdled (trial 1) $(P=0.0144)$ (Table 4). Inoculations with $5.0 \times 10^{3}$ and $1.0 \times 10^{4}$ zoospores $/ \mathrm{ml}$ produced significantly more stem lesions that treatment at $1.0 \times 10^{3}$ zoospore $/ \mathrm{ml}$. Mean stem lesion length ranged from 11.0 to $19.1 \mathrm{~cm}$ across all inoculated treatments in trial 1 . Stem girdling also was observed with all inoculated treatments in trial 1 . Approximately $60.0 \%$ of the stems were girdled when plants were inoculated with $5.0 \times 10^{3}$ zoospores $/ \mathrm{ml}$ and $80.0 \%$ were girdled when inoculated with $1.0 \times 10^{4}$

Table 2. Relationship between the concentration of zoospores (Conc.) of Phytophthora nicotianae applied as water splash dissemination and leaf, petiole, leaf axil, and stem infection of Russet Norkotah potato ${ }^{y}$

\begin{tabular}{|c|c|c|c|c|c|c|}
\hline \multirow[b]{3}{*}{ Conc. (zoospores/ml) } & \multicolumn{5}{|c|}{ Total lesions per plant } & \multirow[b]{3}{*}{ Leaves infected (\%) } \\
\hline & \multirow[b]{2}{*}{ Leaf $^{z}$} & \multirow[b]{2}{*}{ Petiole } & \multicolumn{2}{|c|}{ Axil } & \multirow[b]{2}{*}{ Stem } & \\
\hline & & & Trial 1 & Trial 2 & & \\
\hline 0.0 & $0.0 \mathrm{a}$ & $0.0 \mathrm{a}$ & $0.0 \mathrm{a}$ & $0.0 \mathrm{a}$ & $0.0 \mathrm{a}$ & $0.0 \mathrm{a}$ \\
\hline $1.0 \times 10^{3}$ & $15.4 \mathrm{a}$ & $0.1 \mathrm{a}$ & $1.6 \mathrm{a}$ & $0.0 \mathrm{a}$ & $0.3 \mathrm{ab}$ & $37.7 \mathrm{~b}$ \\
\hline $5.0 \times 10^{3}$ & $105.8 \mathrm{a}$ & $2.6 \mathrm{a}$ & $4.1 \mathrm{~b}$ & $0.3 \mathrm{a}$ & $1.1 \mathrm{bc}$ & $72.6 \mathrm{c}$ \\
\hline $1.0 \times 10^{4}$ & $275.1 \mathrm{~b}$ & $5.9 \mathrm{~b}$ & $4.7 \mathrm{~b}$ & $0.1 \mathrm{a}$ & $1.7 \mathrm{c}$ & $85.8 \mathrm{c}$ \\
\hline$P$ value & 0.0001 & 0.0003 & 0.0033 & 0.5483 & 0.0085 & $<0.0001$ \\
\hline
\end{tabular}

y Each treatment consisted of five replicate plants and the experiment was conducted twice. Assessments were made 4 days after inoculation. Means followed by the same letter do not differ significantly according to Fisher's protected least significant difference $(\alpha=0.05)$. $P$ value signifies the probability of observing a greater value with the $F$ test.

$\mathrm{z}$ Total of all leaflets. 
zoospores $/ \mathrm{ml}$. These same treatments resulted in only 0.0 and $37.5 \%$, respectively, in trial 2 . However, lesion length did not differ significantly $(P=0.0625)$ among zoospore-inoculated treatments in trial 2 (Table 4). Although progeny tuber infections were observed in both trials of this experiment, infection rates did not differ significantly among treatments in either trial (Table 4). Tuber infections by P. nicotianae were 10.0 to $48.0 \%$ in trial 1 . In trial 2 , only the higher inoculum concentrations of $5.0 \times 10^{3}$ and $1.0 \times 10^{4}$ zoospores $/ \mathrm{ml}$ resulted in progeny tuber infections, with incidences of 8.3 and $18.8 \%$, respectively.

Postharvest isolations. Variances for isolate recovery from aboveground stem tissue were not homogeneous and these data are presented separately (Table 5). P. nicotianae was recovered from 11 of the 12 splash-inoculation treatments over both trials (data not shown); isolates were not recovered from belowground stem tissue from the $1.0 \times 10^{3}$ zoospores $/ \mathrm{ml}$ splash-inoculation treatment in trial 2. The lowest rates of recovery from both aboveground and belowground tissue generally were associated with this treatment (Table 5). Although isolates were recovered from aboveground stem tissue of all zoospore-inoculated treatments in both trials, recovery rates did not differ significantly among treatments $(P=0.1349$ and 0.7375$)$. The largest proportion of positive isolations $(60.0 \%)$ was obtained from aboveground stem tissue from plants inoculated with $5.0 \times 10^{3}$ or $1.0 \times 10^{4}$ zoospores $/ \mathrm{ml}$ in trial 1 . Variances of pathogen isolation data from belowground stem tissue from both trials were homogeneous and data were combined for analysis. Significant differences $(P=0.0115)$ and a rate response were observed among treatments (Table 5). Belowground infections were confirmed in $55.0 \%$ of the stems from plants inoculated with $1.0 \times 10^{4}$ zoospores $/ \mathrm{ml}$. This infection rate was significantly greater than that obtained with $1.0 \times 10^{3}$ zoospores $/ \mathrm{ml}$ but not with $5.0 \times 10^{3}$ zoospores $/ \mathrm{ml}$. P. nicotianae was not recovered from tissue obtained from noninoculated control plants.

\section{Discussion}

Little is known about the etiology of tuber rot and foliar blight of potato caused by $P$. nicotianae aside from occasional observations in the field and limited studies involving postharvest tuber inoculations and inoculations of excised potato leaves $(9,14,25,40,48,64,65)$. This probably is due to the intermittent nature of disease occurrences in potato, both spatially and temporally, associated with this pathogen. Results reported here provide some basic information regarding the interaction between $P$. nicotianae and potato. These observations demonstrate that zoospores of $P$. nicotianae are capable of acting as primary inoculum infecting aboveground and belowground portions of the potato plant, and that such infections may have an impact upon development of tuber rot as well. Variability in infection efficiencies observed between trials in both the soil-infestation and splash-inoculation experiments indicate that, even when environmental parameters are well controlled, as in a greenhouse setting, rates of infection induced by $P$. nicotianae attained can be inconsistent. Such variability mirrors observations of foliar blight and tuber rot made under much more rigorous and highly unpredictable environmental conditions present in the field both yearly and across cropping seasons. This finding may partially explain the sporadic nature of outbreaks of $P$. nicotianae tuber rot and foliar blight noted in the United States since $1929(9,25,48,51,64,65)$. However, results of the current study also demonstrate that, when infections do occur, they can severely affect the potato plant, causing seed tuber decay, defoliation, stem girdling, and rot in progeny tubers. Severe losses due to $P$. nicotianae tuber rot (25) and foliar blight (64) have been reported to occur in potato fields under commercial production.

Irregular occurrence of $P$. nicotianae infections in potato also may be associated with dissemination efficiency and long-term survival of the pathogen, both of which could affect initial infections. Examining the entire life history of $P$. nicotianae as it relates to the potato host was beyond the scope of the work reported here but, based upon what is known about other diseases caused by this pathogen, it is possible to make inferences regarding some characteristics of this potato host-pathogen system. Foliar infections and initial infestations are unlikely to be initiated by windblown sporangia due to lack of effective sporulation (64) and noncaducous nature of sporangia $(2,14)$. Only $P$. infestans and $P$. phaseoli are known to readily shed their sporangia into the air without the aid of moving water (13). This is one

Table 3. Relationship between the concentration of zoospores (Conc.) of Phytophthora nicotianae applied as water splash dissemination and relative area under the disease progress curve (RAUDPC) in Russet Norkotah potato ${ }^{z}$

\begin{tabular}{lll}
\hline & \multicolumn{2}{c}{ RAUDPC } \\
\cline { 2 - 3 } Conc. $($ zoospores/ml) & Trial 1 & Trial 2 \\
\hline 0.0 & $0.2 \mathrm{a}$ & $0.1 \mathrm{a}$ \\
$1.0 \times 10^{3}$ & $0.2 \mathrm{a}$ & $0.2 \mathrm{a}$ \\
$5.0 \times 10^{3}$ & $0.4 \mathrm{~b}$ & $0.2 \mathrm{a}$ \\
$1.0 \times 10^{4}$ & $0.4 \mathrm{~b}$ & $0.2 \mathrm{a}$ \\
$P$ value & 0.0008 & 0.0686 \\
\hline
\end{tabular}

${ }^{\mathrm{z}}$ Each treatment consisted of five replicate plants and the experiment was conducted twice. Means followed by the same letter do not differ significantly according to Fisher's protected least significant difference $(\alpha=0.05)$. $P$ value signifies the probability of observing a greater value with the $F$ test.

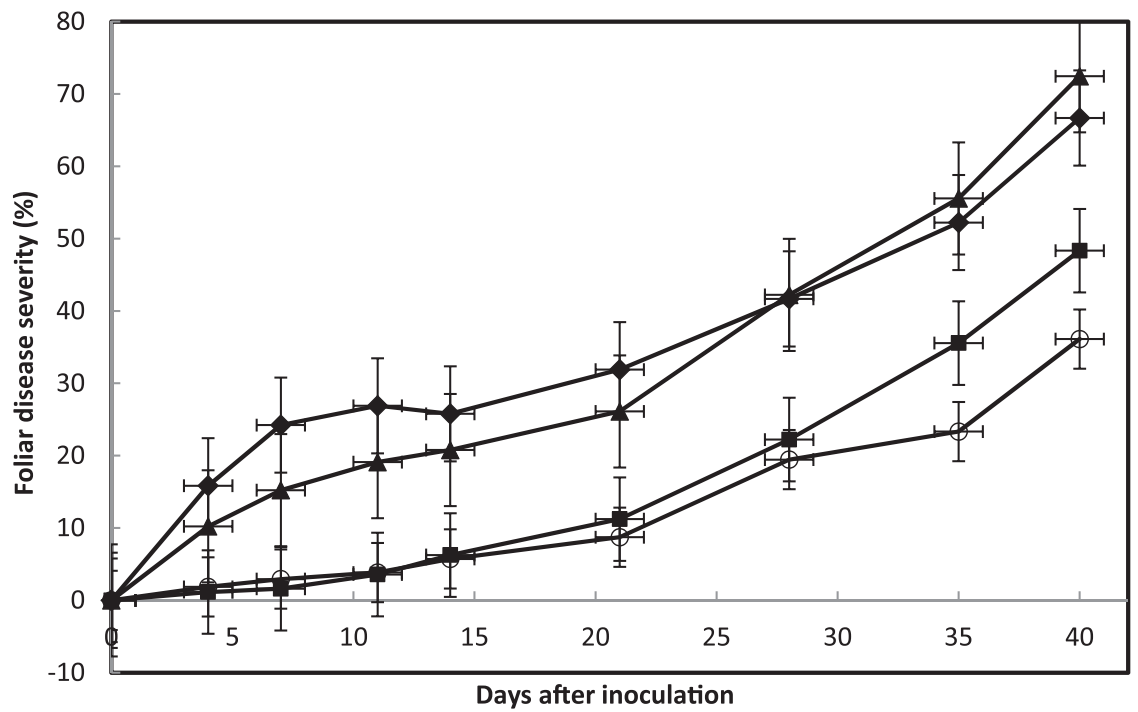

Fig. 1. Effect of zoospore concentration $\left(O=0.0, \boldsymbol{m}=1.0 \times 10^{3}, \boldsymbol{\Delta}=5.0 \times 10^{3}\right.$, and $\quad=1.0 \times 10^{4}$ zoospores $\left./ \mathrm{ml}\right)$ disseminated as simulated water splash on foliar blight development in Russet Norkotah potato. Error bars represent standard error of the mean. 
reason that late blight epidemics of potato caused by $P$. infestans, which produces caducous sporangia, can be devastating. P. nicotianae, typical of most soilborne species of Phytophthora, produces noncaducous sporangia, which are generally retained on the sporangiophore. However, because of their size and motility, zoospores have the ability to move relatively freely through the soil, particularly under saturated conditions $(11,13,54,67)$. The current study with potato confirms this. Infestation of the soil with $P$. nicotianae zoospores resulted in infection of belowground sprouts and decay of seed tubers, significantly affecting plant emergence and tuber yield. Plant emergence and seed tuber rot were dependent on timing of infestation and concentration of zoospore inoculum.

Other observations suggest that oospores may not play a role in the etiology of $P$. nicotianae infections of potato $(34,64,65)$. Based upon our observations and other work $(34,38,42,64,65)$ with $P$. nicotianae, zoospores and chlamydospores are likely the most important propagules in the development of tuber rot and foliar blight of potato. Earlier postharvest inoculation studies with zoospores of $P$. nicotianae demonstrated that tubers could be infected through eyes and wounds $(64,65)$. Results reported here confirm this fact, and also demonstrate that such infections can occur naturally following soil infestation. It is possible that soilborne chlamydospores could be splashed onto the potato foliage in a manner similar to zoospores but the significance of this in relation to disease etiology is unknown. In diseases caused by Phytophthora spp., zoospores are most often considered to be secondary inoculum responsible for plant-to-plant infections but, under soil saturation or flooded conditions, these propagules may serve as primary inoculum $(28,47)$. Outbreaks of $P$. nicotianae foliar blight of potato have been associated with such conditions (64).

The potato is vegetatively propagated; therefore, $P$. nicotianae could be transported into new areas on seed tubers or machinery. However, because dispersal by water is a limiting factor in many diseases caused by Phytophthora spp. (13), the pathogen is most likely introduced into noninfested soil as zoospores in surface water runoff or irrigation water. P. nicotianae has been recovered from a variety of water sources, including well, stream, pond, canal, reservoir, surface runoff, ebb-and-flow nutrient system, and nutrient film irrigation production (29). Isolates of $P$. nicotianae recovered from surface water and a range of host species, host tissues, locations, and mating types have been shown to be pathogenic to potato (65). Although isolates recovered from potato were found to be the most aggressive, those results are significant and demonstrate that isolates from other plant species could be a source of infection for potato. Zoospores can move considerable distances in contaminated water. In studies conducted in irrigation furrows in bell pepper, tomato, and squash fields, $P$. parasitica was found to be dispersed up to $70 \mathrm{~m}$ from the point inoculum sources $(6,49)$. During preliminary greenhouse studies involving soil infestation and foliar water splash inoculation with $P$. nicotianae zoospores, we observed and confirmed belowground stem and tuber infections in control plants. These plants were grown in pots on solid-top benches and the noninoculated controls presumably became infected by zoospores flushed out of the bottom of the pots, reaching adjacent pots via bench surface water flow. Similarly, $P$. parasitica was shown to be disseminated from containerized
Catharanthus roseus plants growing in soil infested with zoospores on greenhouse benches watered via an ebb-and-flow subirrigation system (63). Such observations again demonstrate the ease with which zoospores can move in water and prompted the switch to open-mesh bench tops in the current experiments.

$P$. nicotianae propagules have been shown to be concentrated in the upper $7.6 \mathrm{~cm}$ of the soil in tobacco fields under continuous cultivation, with the highest numbers just below the plant and very low concentrations 15 to $46 \mathrm{~cm}$ away (18). Accumulation near the host plant such as this could be due to attraction of zoospores by root exudates (28). Also, zoospores of Phytophthora spp. exhibit negative geotaxis and tend to move toward the surface of their aquatic environment $(7,8)$. These factors all are important epidemiologically because a larger population of zoospores should be found near the plant and in close proximity to the soil surface or surface of standing water. That would place zoospores in an ideal location for dissemination into the air by falling raindrops, irrigation water, or drip from vegetation and would maximize the efficiency of the splash dispersal mechanism. It has been noted that approximately one billion droplets large enough to carry a zoospore could be splashed up to $1 \mathrm{~m}$ into still air by rain falling $100 \mathrm{~mm}$ onto $1 \mathrm{~m}^{2}$ of ground and, in wind, these droplets could travel many meters from the splash site (23). Rainsplash dispersal has been implicated in diseases caused by several Phytophthora spp., including $P$. parasitica $(1,21,32,37)$.

Splash movement of soil and zoospores and initial foliar infections by $P$. nicotianae usually occur in areas of standing water, areas with poor canopy development, or open ground where some plants are defoliated or have died. Interestingly, in potato fields, these conditions often are found along irrigation tracks where foci of infections are frequently located (64). In studies dealing with rhododendron dieback caused by $P$. parasitica, Kuske and Benson (37) observed that lesion distribution followed a negative dispersal gradient with height from the base of infected plants, and that more lesions clustered on plants nearest areas that pooled during irrigation rainfall. This suggests that water splash from the open puddles significantly increased

Table 5. Relationship between zoospore concentration (Conc.) applied as water splash dissemination and recovery of isolates Phytophthora nicotianae from stem tissue of Russet Norkotah potato ${ }^{\mathrm{z}}$

\begin{tabular}{lccc}
\hline & \multicolumn{3}{c}{ Recovery (\%) } \\
\cline { 2 - 4 } & Aboveground tissue \\
\cline { 2 - 4 } Conc. (zoospores/ml) & Trial 1 & Trial 2 & Belowground tissue \\
\hline 0.0 & $0.0 \mathrm{a}$ & $0.0 \mathrm{a}$ & $0.0 \mathrm{a}$ \\
$1.0 \times 10^{3}$ & $20.0 \mathrm{a}$ & $12.5 \mathrm{a}$ & $11.1 \mathrm{a}$ \\
$5.0 \times 10^{3}$ & $60.0 \mathrm{a}$ & $25.0 \mathrm{a}$ & $22.2 \mathrm{ab}$ \\
$1.0 \times 10^{4}$ & $60.0 \mathrm{a}$ & $10.0 \mathrm{a}$ & $55.0 \mathrm{~b}$ \\
$P$ value & 0.1349 & 0.7375 & 0.0115 \\
\hline
\end{tabular}

${ }^{\mathrm{z}}$ Each treatment consisted of five replicate plants and the experiment was conducted twice. Assessments made at harvest (40 days after inoculation). Means followed by the same letter do not differ significantly according to Fisher's protected least significant difference $(\alpha=0.05)$. $P$ value signifies the probability of observing a greater value with the $F$ test.

Table 4. Relationship between the concentration of zoospores (Conc.) of Phytophthora nicotianae applied as water splash dissemination and stem number, tuber yield, and stem and tuber infections of Russet Norkotah potato ${ }^{\mathrm{z}}$

\begin{tabular}{|c|c|c|c|c|c|c|c|c|c|c|c|}
\hline \multirow[b]{2}{*}{ Conc. (zoospores/ml) } & \multirow[b]{2}{*}{ Stems $(n)$} & \multirow[b]{2}{*}{ Stem FW (g) } & \multirow[b]{2}{*}{ Stem lesions $(n)$} & \multicolumn{2}{|c|}{$\begin{array}{l}\text { Stem lesion } \\
\text { length }(\mathrm{cm})\end{array}$} & \multicolumn{2}{|c|}{$\begin{array}{c}\text { Stems girdled } \\
(\%)\end{array}$} & \multirow[b]{2}{*}{ Tubers (n) } & \multirow[b]{2}{*}{ Tuber FW (g) } & \multicolumn{2}{|c|}{$\begin{array}{l}\text { Progeny tuber } \\
\text { infection }(\%)\end{array}$} \\
\hline & & & & Trial 1 & $\overline{\text { Trial } 2}$ & Trial 1 & $\overline{\text { Trial } 2}$ & & & Trial 1 & Trial 2 \\
\hline$\overline{0.0}$ & $2.0 \mathrm{a}$ & $157.3 \mathrm{a}$ & $0.0 \mathrm{a}$ & $0.0 \mathrm{a}$ & $0.0 \mathrm{a}$ & $0.0 \mathrm{a}$ & $0.0 \mathrm{a}$ & $4.4 \mathrm{a}$ & $163.8 \mathrm{a}$ & $0.0 \mathrm{a}$ & $0.0 \mathrm{a}$ \\
\hline $1.0 \times 10^{3}$ & $1.6 \mathrm{a}$ & $141.2 \mathrm{a}$ & $1.0 \mathrm{a}$ & $11.0 \mathrm{~b}$ & $2.8 \mathrm{a}$ & $20.0 \mathrm{ab}$ & $0.0 \mathrm{a}$ & $3.3 \mathrm{a}$ & $193.3 \mathrm{a}$ & $10.0 \mathrm{a}$ & $0.0 \mathrm{a}$ \\
\hline $5.0 \times 10^{3}$ & $1.7 \mathrm{a}$ & $145.4 \mathrm{a}$ & $3.6 \mathrm{~b}$ & $15.0 \mathrm{~b}$ & $5.5 \mathrm{a}$ & $60.0 \mathrm{bc}$ & $0.0 \mathrm{a}$ & $3.3 \mathrm{a}$ & $135.3 \mathrm{a}$ & $48.0 \mathrm{a}$ & $8.3 \mathrm{a}$ \\
\hline $1.0 \times 10^{4}$ & $1.7 \mathrm{a}$ & $130.1 \mathrm{a}$ & $3.2 \mathrm{~b}$ & $19.1 \mathrm{~b}$ & $7.9 \mathrm{a}$ & $80.0 \mathrm{c}$ & $37.5 \mathrm{a}$ & $3.4 \mathrm{a}$ & $156.9 \mathrm{a}$ & $35.0 \mathrm{a}$ & $18.8 \mathrm{a}$ \\
\hline$P$ value & 0.5687 & 0.6349 & $<0.0001$ & 0.0089 & 0.0625 & 0.0144 & 0.1298 & 0.4142 & 0.2266 & 0.2722 & 0.3386 \\
\hline
\end{tabular}

${ }^{\mathrm{z}}$ Each treatment consisted of five replicate plants and the experiment was conducted twice. Assessments were made at harvest (40 days after inoculation); $n=$ number and FW = fresh weight. Means followed by the same letter do not differ significantly according to Fisher's protected least significant difference $(\alpha=0.05)$. $P$ value signifies the probability of observing a greater value with the $F$ test. 
disease incidence and severity. Additionally, due to the nature of the overall morphology of the potato plant, which includes long trailing vines, infections may result from direct contact of the foliage with surface water or saturated soil. This large, wet biomass of vines provides an ideal environment of high humidity and sites where free water may remain for a considerable amount of time after an irrigation event.

In results reported here, soil deposited on leaves during the splash inoculations often was the focal point of infection sites. This observation suggests that the soil aided the infection process, possibly extending the duration of available moisture on the plant surface or causing microwounds via abrasion. It also is apparent from these experiments that leaf axils may be an important component in disease etiology, because many of the stem and petiole infections were initiated at these sites. Leaf nodes with axillary bud primordia and axillary buds provide loci for zoospores to collect and an excellent moist microenvironment for the infection process to occur. Water can readily run down the petiole shaft, keeping these nodal areas infused with moisture, inoculum, and trapped soil debris. Heavily infected leaves were almost completely chlorotic 5 DAI and leaf axil infections resulted in chlorosis as well. Many infected leaves dropped from the plant and onto the soil in the pots while still green due to abscission at infected axils. $P$. nicotianae could readily be isolated from lesions on these leaves. This infested leaf material was kept moist during the watering operations. It is possible that groundlevel stem infections could be produced from mycelium growing from this debris but progeny tuber infections would most likely be caused by zoospores released into the soil from sporangia produced in the leaf litter. Kuske and Benson (38) demonstrated that $P$. parasitica readily survives in leaf tissue shed from rhododendron plants during typical dieback infections. Leaf litter as a source of inoculum has also been shown to be important in the etiology of other diebacks caused by $P$. cirtophthora (21) and P. ilicis (4). Belowground stem infections and infections of progeny tubers observed in the present study presumably originated from sporulation that occurred on abscised leaf tissue. Because $P$. nicotianae was recovered from asymptomatic stems at harvest, it appears that the infection process is ongoing, and this provides indirect evidence that leaf tissue shed during the progression of the disease could be acting as a continual source of inoculum. However, the possibility that earlier symptomatic infections resulted from inadvertent exposure to zoospores during splash dissemination or the misting processes cannot be completely discounted. Whatever the case, these observations further demonstrate the ability of $P$. nicotianae to infect potato in the soil environment, even as plants approach maturity. The role of foliar blight in the development of belowground infections should not be overlooked because belowground stem infections were verified with all three inoculum treatments and progeny tuber infections were detected in all three foliar inoculation treatments in trial 1 and with the $5.0 \times 10^{3}$ and $1.0 \times 10^{4}$ zoospores $/ \mathrm{ml}$ treatments in trial 2 . Although asymptomatic progeny tuber tissue was not sampled for the presence of $P$. nicotianae, the fact that such infections were detected in stem tissue suggests that progeny tubers similarly could be infected. Such infections would affect the development of postharvest tuber rot.

The short generation time generally associated with Phytophthora spp. contributes to a prodigious reproductive capacity, which can substantially affect disease development. Waterhouse (71) noted sporangial production by $P$. nicotianae within 24 to $48 \mathrm{~h}$. Under conditions used in the current study, initiation of zoosporangia occurred within $1.5 \mathrm{~h}$, sporangia were produced and zoospores were released within $8 \mathrm{~h}$, with mass release of zoospores occurring within 12 to $15 \mathrm{~h}$. With multiple zoospores discharged from each sporangium, low inoculum densities can rapidly result in high levels of disease in the field. Abundant leaf infections, including severe defoliation, occurred within 4 to 7 days in current experiments following foliar inoculations with zoospores at concentrations of $5.0 \times 10^{3}$ and $1.0 \times 10^{4}$ zoospores $/ \mathrm{ml}$.

The results obtained in these experiments highlight the importance of water in the development of foliar blight and tuber rot of potato caused by $P$. nicotianae. As such, disease management should be directly affected by water management practices. The tuber rot phase of $P$. nicotianae infections appears to be similar to pink rot caused by $P$. erythroseptica. Therefore, management strategies employed to control that pathogen, such as planting in well-drained soils and avoiding excessive irrigation, should prove beneficial in controlling tuber rot and foliar blight caused by $P$. nicotianae as well. Although outbreaks of $P$. nicotianae tuber rot and foliar blight can be severe, the foliar phase of the disease is manageable because infections are generally localized in wet, low-lying areas or along irrigator tracks, and may be treated effectively with spot applications of fungicides such as mefenoxam (64) or phosphorous acid, which have proven to be effective against oomycetes. Once infestations are detected, similar areas should be monitored for intrafield development of secondary infection loci spread along surface water flow channels. This study demonstrated that zoospore concentrations capable of causing severe foliar infections also could significantly impact plant emergence, yield, and tuber rot. Foliar infections have the potential of adding inoculum to the soil. Consequently, the most important aspect of $P$. nicotianae foliar blight is that it should be taken as an indicator that the pathogen is present in the field and that the potential for tuber rot is high. Therefore, controlling foliar blight will likely have an impact on the development of tuber rot.

\section{Acknowledgments}

We thank D. Peterson and R. Benz for technical assistance with this project.

\section{Literature Cited}

1. Alfieri, S. A., Jr. 1970. Bougainvillea blight, a new disease caused by Phytophthora parasitica. Phytopathology 60:1806-1808.

2. Al-Hedaithy, S. S. A., and Tsao, P. H. 1979. Sporangium pedicel length in Phytophthora species and the consideration of its uniformity in determining sporangium caducity. Trans. Br. Mycol. Soc. 72:1-13.

3. Benson, D. M., and Jones, R. K. 1980. Etiology of rhododendron dieback caused by four species of Phytophthora. Plant Dis. 64:687-691.

4. Buddenhagen, I. W., and Young, R. A. 1957. A leaf and twig disease of English holly caused by Phytophthora ilicis n. sp. Phytopathology 47:95-101.

5. Bush, E. A., Hong, C., and Stromberg, E. L. 2003. Fluctuations of Phytophthora and Pythium spp. in components of a recycling irrigation system. Plant Dis. 87:1500-1506.

6. Café Filho, A. C., and Duniway, J. M. 1995. Dispersal of Phytophthora capsici and $P$. parasitica in furrow-irrigated rows of bell pepper, tomato and squash. Plant Pathol. 44:1025-1032.

7. Cameron, J. N., and Carlile, M. J. 1977. Negative geotaxis of zoospores of the fungus Phytophthora. J. Gen. Microbiol. 98:599-602.

8. Carlile, M. J. 1983. Motility, taxis and tropism in Phytophthora. Pages 95-107 in: Phytophthora. Its Biology, Taxonomy, Ecology and Pathology. D. C. Erwin, S. Bartnicki-Garcia, and P. Tsao, eds. American Phytopathological Society, St. Paul, MN.

9. Drechsler, C. 1929. A diplanetic species of Phytophthora causing pink rot of potato tubers. Phytopathology 19:92

10. Dukes, P. D., and Apple, J. L. 1962. Relationship of zoospore production potential and zoospore motility with virulence in Phytophthora parasitica var. nicotianae. Phytopathology 52:191-193.

11. Duniway, J. M. 1976. Movement of zoospores of Phytophthora cryptogea in soils of various textures and matric potentials. Phytopathology 66:877-882.

12. Duniway, J. M. 1979. Water relations of water molds. Annu. Rev. Phytopathol. 17:431-460.

13. Duniway, J. M. 1983. Role of physical factors in the development of Phytophthora diseases. Pages 175-187 in: Phytophthora: Its Biology, Taxonomy, Ecology, and Pathology. D. C. Erwin, S. Bartnicki-Garcia, and P. H. Tsao, eds. American Phytopathological Society, St. Paul, MN.

14. Erwin, D. C., and Ribeiro, O. K. 1996. Phytophthora Diseases Worldwide. American Phytopathological Society, St. Paul, MN.

15. Ferguson, A. J., and Jeffers, S. N. 1999. Detecting multiple species of Phytophthora in container mixes from ornamental crop nurseries. Plant Dis. 83:1129-1136.

16. Fiers, M., Edel-Hermann, V., Chatot, C., Le Hingrat, Y., Albouvette, C., and Steinberg, C. 2012. Potato soil-borne diseases. A review. Agron. Sustain. Dev. 32:93-132.

17. Fitt, B. D. L., McCartney, H. A., Creighton, N. F., Lacey, M. E., and Walklate, P. J. 1988. Dispersal of Rhynchosporium secalis conidia from infected barley leaves or straw by simulated rain. Ann. Appl. Biol. 112:49-59.

18. Flowers, R. A., and Hendrix, J. W. 1972. Population density of Phytophthora parasitica var. nicotianae in relation to pathogenesis and season Phytopathology 62:474-477. 
19. Fry, W. E. 1978. Quantification of general resistance of potato cultivars and fungicide effects for integrated control of potato late blight. Phytopathology 68:1650-1655.

20. Gallegly, M. E., and Hong, C. 2008. Phytophthora-Identifying Species by Morphology and DNA Fingerprints. American Phytopathological Society, St. Paul, MN.

21. Gerlach, W. W. P., Hoitink, H. A. J., and Schmitthenner, A. F. 1976. Phytophthora citrophthora on Pieris japonica: Infection, sporulation and dissemination. Phytopathology 66:302-308.

22. Gevens, A. J., Donahoo, R. S., Lamour, K. H., and Hausbeck, M. K. 2007. Characterization of Phytophthora capsici from Michigan surface irrigation water. Plant Dis. 97:421-428.

23. Gregory, P. H. 1983. Some major epidemics caused by Phytophthora. Pages 271-278 in: Phytophthora: Its Biology, Taxonomy, Ecology, and Pathology. D. C. Erwin, S. Bartnicki-Garcia, and P. H. Tsao, eds. American Phytopathological Society, St. Paul, MN.

24. Gregory, P. H., Guthrie, E. J., and Bunce, M. E. 1959. Experiments on splash dispersal of fungus spores. J. Gen. Microbiol. 20:328-354.

25. Grisham, M. P., Taber, R. A., and Barnes, L. W. 1983. Phytophthora rot of potatoes in Texas caused by Phytophthora parasitica and P. cryptogea. Plant Dis. 67:1258-1261.

26. Grove, G. G., Madden, L. V., and Ellis, M. A. 1985. Splash dispersal of Phytophthora cactorum from infected strawberry fruit. Phytopathology 75 : 611-615.

27. Guest, D. 2007. Black pod: Diverse pathogens with a global impact on cocoa yield. Phytopathology 97:1650-1653.

28. Hickman, C. J., and Ho, H. H. 1966. Behavior of zoospores in plantpathogenic phycomycetes. Annu. Rev. Phytopathol. 4:195-214.

29. Hong, C. X., and Morman, G. W. 2005. Plant pathogens in irrigation water: Challenges and opportunities. Crit. Rev. Plant Sci. 24:189-208.

30. Hoy, M. W., Ogawa, J. M., and Duniway, J. M. 1984. Effects of irrigation on buckeye rot of tomato fruit caused by Phytophthora parasitica. Phytopathology 74:474-478.

31. Hulvey, J., Gobena, D., Finley, L., and Lamour, K. 2010. Co-occurrence and genotype distribution of Phytophthora species recovered from watersheds and plant nurseries of eastern Tennessee. Mycologia 102:1127-1133.

32. Hunter, J. E., and Kunimoto, R. K. 1974. Dispersal of Phytophthora palmivora sporangia by wind-blown rain. Phytopathology 64:202-206.

33. Hwang, J., and Benson, D. M. 2005. Identification, mefenoxam sensitivity, and compatibility type of Phytophthora spp. attacking floriculture crops in North Carolina. Plant Dis. 89:185-190.

34. Kannwischer, M. E., and Mitchell, D. J. 1981. Relationships of numbers of spores of Phytophthora parasitica var. nicotianae to infection and mortality of tobacco. Phytopathology 71:69-73.

35. Kliejunas, J. T., and Ko, W. H. 1976. Dispersal of Phytophthora cinnamomi on the island of Hawaii. Phytopathology 66:457-460.

36. Koltz, L. J., Wong, P. P., and DeWolfe, T. A. 1959. Survey of irrigation water for the presence of Phytophthora spp. pathogenic to citrus. Plant Dis. Rep. 43: 830-832.

37. Kuske, C. R., and Benson, D. M. 1983. Survival and splash dispersal of Phytophthora parasitica, causing dieback of rhododendron. Phytopathology 73:1188-1191.

38. Kuske, C. R., and Benson, D. M. 1983. Overwintering and survival of Phytophthora parasitica causing dieback of rhododendron. Phytopathology 73:1192-1196.

39. Lacey, J. 1967. The role of water in the spread of Phytophthora infestans in the potato crop. Ann. Appl. Biol. 59:245-255.

40. Lambert, D. H., and Salas, B. 2001. Pink rot. Pages 33-34 in: Compendium of Potato Diseases, 2nd ed. W. R. Stevenson, R. Loria, G. D. Franc, and D. P. Weingartner, eds. American Phytopathological Society, St. Paul, MN

41. Leonberger, A. J., Speers, C., Ruhl, G., Creswell, T., and Beckerman, J. L. 2013. A survey of Phytophthora spp. in Midwest nurseries, greenhouses and landscapes. Plant Dis. 97:635-640.

42. Lutz, A. L., Menge, J. A., and Ferrin, D. M. 1991. Increased germination of propagules of Phytophthora parasitica by heating citrus soils sampled during winter. Phytopathology 81:865-872.

43. Madden, L. V., and Ellis, M. A. 1990. Effects of ground cover on splash dispersal of Phytophthora cactorum from strawberry fruits. J. Phytopathol. 129:170-174.

44. Madden, L. V., Yang, X., and Wilson, L. L. 1996. Effects of rain intensity on splash dispersal of Colletotrichum acutatum. Phytopathology 86:864-874.

45. McIntosh, D. L. 1966. The occurrence of Phytophthora spp. in irrigation systems in British Columbia. Can. J. Bot. 44:1591-1596.

46. Millikin, G. A., and Johnson, D. E.1992. One-way treatment structure in a completely randomized design with heterogeneous errors.Pages 16-28 in:
Analysis of Messy Data, Vol. 1. Designed Experiments. Chapman and Hall, London.

47. Mitchell, D. J., Kannwischer, M. E., and Moore, E. S. 1978. Relationship of numbers of Phytophthora cryptogea zoospores to infection and mortality of watercress. Phytopathology 68:1446-1448.

48. Mulrooney, R. P., Carroll, R. B., Morehart, A. L., and Wittington, D. P. 1994. Potato pink rot in Delaware and New Jersey caused by Phytophthora nicotianae. (Abstr.) Phytopathology 84:546.

49. Neher, D., and Duniway, J. M. 1992. Dispersal of Phytophthora parasitica in tomato fields by furrow irrigation. Plant Dis. 76:582-586.

50. Olson, H. A., and Benson, D. M. 2011. Characterization of Phytophthora spp. on floriculture crops in North Carolina. Plant Dis. 95:1013-1020.

51. Person, L. H., and Nielsen, L. W. 1969. Potato blight caused by Phytophthora parasitica in North Carolina. (Abstr.) Phytopathology 59:117.

52. Reynolds, K. M., Bulger, M. A., Madden, L. V., and Ellis, M. A. 1987. New methods using simulated rain to study the splash dispersal of plant pathogens. Phytopathology 77:921-926.

53. Reynolds, K. M., Bulger, M. A., Madden, L. V., and Ellis, M. A. 1989. Splash dispersal of Phytophthora cactorum from infected strawberry fruit by simulated canopy drip. Phytopathology 79:425-432.

54. Ristaino, J. B., Duniway, J. M., and Marois, J. J. 1988. Influence of frequency and duration of furrow irrigation on the development of Phytophthora root rot and yield in processing tomatoes. Phytopathology 78:1701-1706.

55. Ristaino, J. B., and Gumpertz, M. L. 2000. New frontiers in the study of dispersal and spatial analysis of epidemics caused by species of the genus Phytophthora. Annu. Rev. Phytopathol. 38:541-576.

56. Rossi, V., and Caffi, T. 2012. The role of rain in dispersal of the primary inoculum of Plasmopara viticola. Phytopathology 102:158-165.

57. Schwingle, B. W., Smith, J. A., and Blanchette, R. A. 2007. Phytophthora species associated with diseased woody ornamentals in Minnesota nurseries. Plant Dis. 91:97-102.

58. Secor, G. A., and Gudmestad, N. C. 1999. Managing fungal diseases of potato Can. J. Plant Pathol. 21:213-221.

59. Shaner, G., and Finney, R. E. 1977. The effect of nitrogen fertilization on the expression of slow-mildewing resistance in Knox wheat. Phytopathology 67: 1051-1056.

60. Sherbakoff, C. D. 1917. Buckeye rot of tomato fruit. Phytopathology 7: 119-129.

61. Shokes, F. M., and McCarter, S. M. 1979. Occurrence, dissemination, and survival of plant pathogens in surface irrigation ponds in southern Georgia. Phytopathology 69:510-516.

62. Stamps, D. J. 1978. Phytophthora erythroseptica. Descriptions of Pathogenic Fungi and Bacteria, No. 593. Commonwealth Mycological Institute, Kew, England.

63. Strong, S. S., Behe, B. K., Deneke, C. F., Bowen, K. L., and Keever, G. J 1997. Cultivar and spacing effects on transmission of Phytophthora parasitica in an ebb-and-flow subirrigation system. Plant Dis. 81:89-95.

64. Taylor, R. J., Pasche, J. S., Gallup, C. A., Shew, H. D., and Gudmestad, N. C. 2008. A foliar blight and tuber rot of potato caused by Phytophthora nicotianae: New occurrences and characterization of isolates. Plant Dis. 92:492-503.

65. Taylor, R. J., Pasche, J. S., Shew, H. D., Lannon, K. R., and Gudmestad, N. C. 2012. Tuber rot of potato caused by Phytophthora nicotianae: Isolate aggressiveness and cultivar susceptibility. Plant Dis. 96:693-704.

66. Thomson, S. V., and Allen, R. M. 1974. Occurrence of Phytophthora species and other potential plant pathogens in recycled irrigation water. Plant Dis. Rep. 58:945-949.

67. Thomson, S. V., and Allen, R. M. 1976. Mechanisms of survival of zoospores of Phytophthora parasitica in irrigation water. Phytopathology 66:1198-1202.

68. Timmer, L. W., and Menge, J. A. 1989. Phytophthora-induced diseases. Pages 22-24 in: Compendium of Citrus Diseases. J. O. Whiteside, S. M. Garnsey, and L. W. Timmer, eds. American Phytopathological Society, St. Paul, MN.

69. Trione, E. J., and Roth, L. F. 1957. Aerial infection of Chamaecyparis by Phytophthora lateralis. Plant Dis. Rep. 41:211-215.

70. Tucker, C. M. 1931. Taxonomy of the genus Phytophthora de Bary. Univ. Mo. Agric. Exp. Stn. Res. Bull. 153.

71. Waterhouse, G. M. 1931. The production of conidia in the genus Phytophthora. Trans. Br. Mycol. Soc. 15:311-321.

72. Weste, G. 1983. Population dynamics and survival of Phytophthora. Pages 237-257 in: Phytophthora: Its Biology, Taxonomy, Ecology, and Pathology. D. C. Erwin, S. Bartnicki-Garcia, and P. H. Tsao, eds. American Phytopathological Society, St. Paul, MN.

73. Yamak, F., Peever, T. L., Grove, G., and Boal, R. J. 2002. Occurrence and identification of Phytophthora spp. pathogenic to pear fruit in irrigation water in the Wenatchee River Valley of Washington State. Phytopathology 92:1210-1217. 